\title{
Aspek Regulasi dan Kewenangan Penegakan Hukum Pajak Reklame
}

\author{
Tinara Aisyah Nikita* \\ University of Pembangunan Nasional Veteran East Java, Surabaya, \\ Indonesia
}

\section{Adhitya Widya Kartika \\ University of Pembangunan Nasional Veteran East Java, Surabaya, Indonesia}

\begin{abstract}
The Mayor's Regulation Number 21 of 2018 licenses procedure and other matters that the taxpayer must obey. This study analyzed the effectiveness of law enforcement on the late-payment of advertisement tax in Surabaya. This study used empirical legal research that observed the effectiveness of the law in society and how the law works in society. The data collected were from documentation from literature and legislation, observation in the community, and interviews with related parties. It showed that law enforcement was effective but with several obstacles experienced in enforcing the law. In particular, it dealt with the COVID-19 pandemic as the challenge that required new conditioning according to the recommendations from the central government. This study concluded that the law enforcement of billboard tax payments in Surabaya is quite effective due to the achievement of tax revenue targets that always reach the target. However, there are still many obstacles faced, and several solutions deal with these obstacles.
\end{abstract}

KEYWORDS: Advertisement Tax, Billboard Tax, Law Enforcement, Tax,

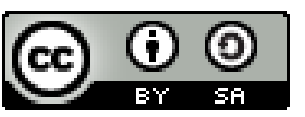

Copyright $\odot 2021$ by Author(s)

This work is licensed under a Creative Commons Attribution-ShareAlike 4.0 International License. All writings published in this journal are personal views of the authors and do not represent the views of this journal and the author's affiliated institutions.

\section{HOW TO CITE:}

Nikita, Tinara Aisyah \& Adhitya Widya Kartika, "Aspek Regulasi dan Kewenangan

Penegakan Hukum Pajak Reklame" (2021) 1:2 Jurnal Kajian Pembaruan Hukum 249-284.

DOI: <https://doi.org/10.19184/jkph.v1i2.24394>.

Submitted: 24/02/2021 Reviewed: 29/02/2021 Revised: 10/03/2021 Accepted: 15/07/2021 


\section{PENDAHULUAN}

Sebagian besar pertumbuhan ekonomi suatu negara dipengaruhi oleh efektivitas dari kebijakan fiskal yang diterapkan oleh pemerintah. Implikasinya, pemerintah wajib menerbitkan berbagai produk hukum berkenaan dengan kebijakan fiskal. Hal ini dilakukan agar seluruh elemen fiskal dapat terlegitimasi dan dapat berjalan secara efektif serta optimal, tak terkecuali mengenai pengaturan pajak. ${ }^{1}$ Pajak adalah elemen primer yang menentukan arah perkembangan kondisi ekonomi suatu negara. Pajak dianggap sebagai 'alat' pemerintah yang esensial untuk membangun infrastruktur fisik dan non-fisik dari suatu negara agar dapat dinikmati oleh seluruh warga negara. Pajak inilah yang menjadi pilar keberlangsungan siklus ekonomi yang stabil pada suatu wilayah. ${ }^{2}$ Berdasarkan hakikatnya, pajak memiliki dua fungsi. ${ }^{3}$ Pertama, fungsi anggaran untuk melunasi pengeluaran yang dilakukan pemerintah dalam membangun fasilitas umum serta pengeluaran lainnya. Kedua, fungsi pengaturan untuk membantu pemerintah mengatur sebuah kebijakan demi mencapai suatu tujuan bagi pemerintahan.

Di sisi lain, pajak merupakan salah satu wujud penerapan konsep otonomi daerah; sebagaimana ketentuan yang tercantum dalam Pasal 9 Undang-Undang Nomor 23 tahun 2014 tentang Pemerintahan Daerah (selanjutnya disebut dengan UU Pemda). Bahkan, UU Pemda memberikan klasifikasi berkenaan pajak yang menjadi urusan pemerintahan antara pusat dan daerah; dengan harapan dapat

1 Rizka E Parinduri et al, "Effect of Tax Amnesty and Government Expenditures on Economic Growth in Indonesia" (2020) 7:11 Int J Res Rev 367-370 at 367.

2 Ibid at 370.

3 Michelle J Naharto \& Elisa Tjondro, "Analisis Tujuan Pemungutan Serta Pengertian Penghasilan Menurut Perpajakan dan Persepuluhan Bagi Wajib Pajak Orang Pribadi" (2014) 4:1 Tax Account Rev 1-14 at 4. 
meningkatkan kualitas masyarakat dengan prinsip demokrasi, keadilan, dan keistimewaan dalam sistem Negara Indonesia. Lumrahnya, penerimaan pajak mencapai tiga-perempat dari seluruh pendapatan nasional. ${ }^{4}$ Dengan demikian, pajak memberikan kontribusi yang besar terhadap pemabangunan negara; mulai dari tingkat pusat sampai ke daerah.

Pajak memiliki pengaruh terhadap pertumbuhan ekonomi masyarakat. ${ }^{5}$ Ketika pajak dikumpulkan dari masyarakat, maka pajak merupakan bentuk pendapatan masyarakat yang dibayarkan kepada pemerintah. Sehingga, pengaturan pajak merupakan hal yang sangat penting untuk menentukan nilai pajak yang diminta oleh negara- kepada masyarakat. ${ }^{6}$ Pengaruh penerimaan pajak pada pertumbuhan ekonomi dapat diukur dari beberapa poin; salah satunya adalah dari poin kesediaan pajak. ${ }^{7}$ Kesediaan Pajak adalah pedoman yang dikondisikan seseorang untuk menyokong belanja negara dengan tidak mendapatkan imbalan secara langsung. ${ }^{8}$ Masyarakat yang memiliki moral perpajakan diartikan sebagai masyarakat yang memiliki dorongan dari dalam diri untuk patuh dan tertib membayar pajak secara sukarela. ${ }^{9}$ Faktor lain yang

4 David Tan \& Lu Sudirman, "Final Income Tax: A Classic Contemporary Concept To Increase Voluntary Tax Compliance Among Legal Profession in Indonesia" (2020) 5:1 J Indones Leg Stud 125-170 at 138.

5 Naharto \& Tjondro, supra note 5 at 8.

6 Ibid at 9.

7 Arfah H Saragih, "Pengaruh Penerimaan Pajak Terhadap Pertumbuhan Ekonomi di Indonesia" (2018) 3:1 Sist Inf Keuang Audit dan Perpajak 17-27 at 25.

8 Ratih Kumala, “Factors That Influence MSME Taxpayer's Willingness to Pay Tax After the Implementation of the Government Rules Number 23 of 2018" (2019) 1:1 Ilomata Int J Tax Account 18-25 at 19.

9 Nur I Pujiati, Syamsu Alam \& Amiruddin, "Penggelapan Pajak Tinjauan Moral Perpajakan (Studi Kasus Kantor Pelayanan Pajak Pratama Makassar Selatan)" (2021) 4:1 AMNESTY J Ris Perpajak 86-98 at 89. 
memengaruhi kesadaran perpajakan adalah adanya norma subjektif berupa pengaruh yang diberikan oleh lingkungan. ${ }^{10}$

Kesadaran pajak dapat berkembang apabila pemerintah mampu menjamin transparansi yang baik. ${ }^{11}$ Kurangnya pengetahuan juga menjadi salah satu faktor tinggi banyaknya penghindaran pajak ${ }^{12}$; oleh sebab, para akademisi serta jajaran lainnya juga masih kurang mengembangkan manajemen pengetahuan mengenai perpajakan ${ }^{13}$. Padahal, pengetahuan mengenai perpajakan cukup luas dan melimpah untuk dipahami dan didalami. Ketika akademisi dapat mengembangkan manajemen pengetahuan tentang pajak dengan bahasa yang bisa dipahami oleh orang awam dan seluruh lapisan masyarakat, maka menumbuhkan peluang pula mengenai peningkatan kesadaran pajak oleh masyarakat. ${ }^{14}$

Hakikatnya, konsep pengetahuan pajak dibagi menjadi tiga, antara lain: pengetahuan umum mengenai Ketentuan Umum dan Tata Cara Perpajakan; pengetahuan mengenai perpajakan di Indonesia; pengetahuan mengenai funsi perpajakan. ${ }^{15}$ Menurut Spilker, jenis

10 Sitti R Sudirman, Darwis Lannai \& Hajering, "Pengaruh Norma Subjektif, Kewajiban Moral, dan Pemahaman Peraturan Pajak Terhadap Kepatuhan Wajib Pajak Pada KPP Pratama Makassar Utara" (2020) 3:2 AMNESTY J Ris Perpajak 164-190 at 175.

11 Khoirul Fuad \& Lutfi Khusfiyah, "Revealing Awareness and Compliance of Tax (Case Study in Tax Ofiice (KPP) Pratama Jepara" (2019) 4:2 J Appl Account Tax.At126.

12 Hendra Permana \& Nofryanti, "Pengaruh Faktor Pendidikan, Pengalaman Kerja, dan Pelatihan terhadap Pengetahuan Aparatur Pajak tentang Tax Avoidance (Studi Kasus Pada Kantor Pelayanan Pajak Pratama Kebayoran Baru Tiga)" (2016) 4:1 J Ilm Akunt Univ Pamulang at 832-848 at 842.

13 Ibid at 843.

14 Gatot Subroto, "Knowledge Management in Tax Administration: A Case Study in Indonesia" (2020) 1:2 Scientax 203-235 at 206-208.

15 Wirmie E Putra, Indra L Kusuma \& Maya W Dewi, "Analisis Faktor-Faktor yang Mempengaruhi Kepatuhan Wajib Pajak (Studi Kasus pada Wajib Pajak 
pengetahuan perpajakan yang dibutuhkan adalah pengetahuan deklaratif mengenai fakta dan konsep perpajakan dan prosedural mengenai pengetahuan tentang sistem perpajakan. ${ }^{16}$ Adapula faktor negatif yang mengakibatkan hambatan untuk meningkatkan kesadaran perpajakan, salah satunya perasaan tidak pernah mendapatkan timbal balik dari pajak yang dibayarkan; oleh karena masyarakat merasa bahwa pembangunan masih belum merata. ${ }^{17} \mathrm{Hal}$ tersebut biasanya menyasar pada tindakan agresivitif pajak yang dilakukan seseorang dan/atau perusahaan. ${ }^{18}$

Agresivitas pajak adalah tindakan perusahaan untuk mengurangi kewajiban pajak mereka; biasanya dengan memanfaatkan celah hukum yang berlaku. ${ }^{19}$ Oleh karena untuk menanggulangi tindakan itu, pembuat kebijakan melihat penghindaran pajak perusahaan sebagai masalah atau menganggap biaya pembatasan itu terlalu tinggi. ${ }^{20} \mathrm{Hal}$ ini menunjukkan sebenarnya masih banyak masalah yang terjadi pada penghindaran pajak oleh perusahaan-perusahaan; apalagi yang tidak sesuai dengan domisili perusahaan, misal perusahaan yang melakukan ekspansi ke negara lain dan memasang

Orang Pribadi dan Badan di Wilayah Kota Jambi" (2019) 20:1 J Akunt Dan Pajak 43-54 at 52.

16 Lutfi H Ali Al-Ttaffi, Said A Bin-Nashwan \& Muneer R Amrah, "The Influence Of Tax Compliance Behaviour: A Case of Yemeni Individual Taxpayers" (2020) 10:2 J Bus Manag Account 15-30 at 19.

17 Permenas Djaha \& Ni Luh Putu Sri Purnama Pradnyani, "Faktor Pelayanan Publik, Informasi Perpajakan, dan Kepatuhan Wajib Pajak dalam Meningkatkan Kesadaran Masyarakat Membayar Pajak" (2019) 2:2 JEMAP J Ekon Manaj Akunt Dan Perpajak 251-266 at 252.

18 Liana Susanto, Yanti \& Viriany, “Faktor-Faktor Yang Mempengaruhi Agresivitas Pajak" (2018) 23:1 J Ekon 10-19 at 14-15.

19 Luk Luk Fuadah \& Umi Kalsum, "The Impact of Corpaorate Social Responsibility on Firm Value: The Role of Tax Aggresiveeness in Indonesia" (2021) 8:3 Tax Account Rev 209-216 at 209.

${ }^{20}$ Ruth Mason, "The Transformation of International Tax" (2020) 114:3 Am J Int Law. at 356. 
reklame untuk menampilkan produk yang dijual kepada calon-calon pembeli.

Penghindaran pajak biasanya menjadi keputusan pimpinan yang dengan sadar dan sengaja. ${ }^{21}$ Hal itu dilakukan dengan tidak melakukan pelaporan atau melakukan pelaporan tetapi tidak sesuai dengan keadaan sesungguhnya. ${ }^{22}$ Latar belakang kecurangan dalam pelaporan laporan keuangan perusahaan biasanya dikarenakan conflict of interest antara manajemen dengan investor. ${ }^{23}$ Selain itu, hal yang menjadi faktor penghindaran pajak adalah bilamana perusahaan memiliki aset tetap yang semakin besar, maka fenomena penghindaran pajak juga semakin sering terjadi. Aset tetap perusahaan akan terus mengalami penyusutan; sehingga timbul biaya penyusutan dalam laporan keuangan. ${ }^{24}$

Perihal yang menjadi penentu penghindaran pajak dapat dikelompokkan menjadi empat kelompok oleh Fischer, antara lain: struktur sistem perpajakan, penalti, peluang deteksi dan kerumitan sistem pajak; sikap dan persepsi seperti keadilan, etika, dan pengaruh teman sebaya; peluang ketidakpatuhan seperti tingkat pendapatan, sumber pendapatan, dan pekerjaan; faktor demografi

21 Ari B Kristanto, "Faktor Finansial dan Non Finansial Yang Mempengaruhi Agresivitas Pajak Di Indonesia" (2016) 16:1 Media Ris Akunt Audit Inf. at 57.

22 Aditya K Wardani, Eva Anggra \& Amirah, "Pengaruh Karakteristik Perusahaan, Good Corporate Governance (GCG), dan Corporate Social Responsibility (CSR) Terhadap Penghindaran Pajak (Tax Avoidance)" (2016) 7:2 PERMANA. at 1-2.

23 Dimas B Prakoso \& Wahyu Setiyorini, "Pengaruh Fraud Diamond Terhadao Indikasi Kecurangan Laporan Keuangan (Studi Pada Perusahaan Perkebunan yang Terdaftar di Bursa Efek Indonesia Tahun 2015-2019)" (2021) 7:2 J Akunt Dan Perpajak. at 49.

${ }^{24}$ Levana D Prawati \& Jesica P Uli Hutagalung, "The Effect of Capital Intensity, Executive Characteristics, and Sales Growth on Tax Avoidance" (2020) 7:1 J Appl Finance Account. at 1. 
seperti usia, jenis kelamin, dan pendidikan. ${ }^{25}$ Oleh karena itu, kepatuhan pembayaran pajak adalah konsekuensi logis atas kewajiban warga negara dengan melaksanakan kewajiban membayar pajak sesuai dengan jumlah yang ditagih dan dibayar tepat waktu. ${ }^{26}$ Kepatuhan tersebut juga mencakup aspek subjek pemasaran, baik itu perorangan maupun institusi; mengingat pemasaran merupakan alat untuk menunjukkan eksistensi nilai dasar subjek pajak tersebut agar mendapatkan keuntungan. ${ }^{27}$

Pemasaran atau seringkali dianggap periklanan sejatinya merupakan komunikasi kelompok dengan biaya tertentu melalui sebuah media dan dilakukan oleh perusahaan, lembaga non-laba, serta individu. ${ }^{28}$ Agar mencapai keuntungan yang besar dalam menjalankan sebuah bisnis, dibutuhkan strategi pemasaran yang jitu untuk mencapai keuntungan bagi perusahaan; salah satunya melalui pemasangan reklame. Reklame dapat diartikan secara luas sebagai suatu desain dalam bentuk gambar atau teks, yang bertujuan untuk menunjukkan, mengundang, menawarkan, atau menyediakan produk barang atau jasa atau layanan kepada penerima pesan reklame dengan menggunakan cara yang menarik yaitu mengarah kepada kepemilikan, penggunaan, atau pembelian produk. Berdasarkan

25 Harun Ur Rashid, “Taxpayer's Attitude Towards Tax Evasion in a Developing Country: Do the Demographic Characterics Matter?" (2020) 9:2 Int J Appl Behav Econ. at 2

${ }^{26}$ Cindy G T June, Unti Ludigdo \& Lilik Purwanti, “Menggali Makna Kepatuhan Wajib Pajak Usaha Mikro" (2021) 5:1 J Akunt Dan Pajak. at 7.

27 Indri Suryani \& Afriapollo Syafarudin, "Effect of Sales Promotion on Purchasing Decisions" (2021) 2:2 Ilomata Int J Tax Account. at 124.

28 Delfia \& Aftoni Sutanto, "Pengaruh Biaya Reklame dan Periklanan Pada PT. PAPUA PASIFIK PERMAI JAYAPURA (Studi Kasus Periode 2014-2018)" (2020) 8:1 E-J Apresiasi Ekon. At 31. 
segmentasi penggunaanya, jenis reklame dibagi atas dua hal; reklame komersial dan reklame non-komersial. ${ }^{29}$

Reklame komersial memiliki tujuan agar konsumen membeli atau mengkonsumsi produk yang ada dalam reklame tersebut; sehingga perusahaan yang memiliki produk tersebut dapat mendapatkan untung baik secara penjualan produk, penggunaan produk, maupun nama sebuah produk yang semakin dikenal dikalangan konsumen dari badan usaha swata atau milik negara. Sedangkan reklame nonkomersial -sering juga disebut iklan layanan masyarakat- memiliki muatan yang berisi tentang pesan moral atau himbauan untuk melaksanakan atau menghindari sesuatu. Kedua jenis reklame ini semakin diminati oleh masyarakat sebagai 'senjata' untuk mendapatkan para konsumen, mengingat manfaat reklame sebenarnya cukup banyak; tidak hanya mempromosikan sebuah barang, jasa, atau orang; tapi juga bisa mempromosikan sebuah acara khusus, memuat ucapan perayaan hari besar, memberikan peringatan akan sesuatu hal, dan lain sebagainya.

Seiring banyaknya usaha yang membutuhkan cara pemasaran dengan memasang reklame membuat pemerintah daerah merancang suatu produk hukum; tak terkecuali Pemerintah Kota Surabaya yang menerbitkan Peraturan Walikota Surabaya Nomor 21 Tahun 2018 Tentang Tata Cara Penyelenggaraan Reklame (selanjutnya disebut dengan Perwali TCPR). Pada prinsipnya, penyelenggaraan reklame memiliki beragam proses perizinan dan pengawasan. Pelaksanaan penyelenggaraan reklame dilakukan mulai dari masalah perizinan, kepemilikan, penentuan lokasi, masa izin reklame, pemenuhan kewajiban-kewajiban. Akibat dari hal itu, salah satu kewajiban

29 Vanya K M Putri, “Jenis- Jenis Reklame”, Kompas.com (January 2021), online: <https://www.kompas.com/skola/read/202a/01/27/145328869/jenis-jenisreklame>. 
penyelenggara reklame adalah membayar pajak reklame. Kehadiran Perwali TCPR didasarkan karena penyelenggaraan reklame berkaitan dengan tata kota; dan bertalian pula dengan perekonomian daerah. Oleh karenanya, diperlukan penegakan hukum yang tegas bilamana terdapat banyak jenis dan bentuk reklame yang melanggar ketentuan; serta kesadaran wajib pajak reklame yang masih kurang. Implementasi penegakan hukum oleh Pemkot Surabaya -dalam hal ini dilakukan Badan Pengelola Keuangan dan Pajak Daerah Kota Surabaya (selanjutnya disebut dengan BPKPD)- berdasarkan Perwali TCPR diwujudkan dalam bentuk pemasangan label yang bertuliskan “MATERI INI BELUM MEMBAYAR PAJAK REKLAME". Strategi ini dilakukan agar wajib pajak reklame merasa malu; lantaran produk yang dipasarkan dalam bentuk reklame tersebut belum membayar pajak. Ketika sebuah usaha yang diketahui belum membayar pajak dan disiarkan bahwa usaha tersebut belum membayar pajak, maka hal tersebut dapat memengaruhi menurunnya jumlah permintaan dari konsumen; bahkan, efek yang lebih rumit dapat muncul, seperti adanya pengaruh pada nilai saham sebuah usaha.

Sehingga, langkah tersebut adalah refleksi bahwa wajib pajak memiliki kewajiban hukum dan moral agar segera membayarkan pajak secara tepat waktu. Berbagai pernyataan di atas mendorong peneliti untuk mengkaji dua isu hukum. Pertama, bagaimana aspek regulasi dan kewenangan penegakan hukum atas keterlambatan pembayaran pajak reklame berdasarkan Perwali TCPR? Kedua, bagaimana kendala dan penyelesaian yang dihadapi Badan Pengelola Keuangan dan Pajak Daerah Kota Surabaya dalam menegakkan Perwali TCPR?

Penelitian ini merujuk pada tiga penelitian terdahulu. Penelitian pertama dilakukan oleh Agnesia Margaretha Gunawan (2020) dengan judul "Studi Deskriptif Tentang Efektifitas Pengaturan 
Perizinan Reklame di Kota Surabaya". Hasil penelitian tersebut menunjukkan bahwa kurangnya pengawasan terhadap perizinan penyelenggaraan reklame di Surabaya berakibat pada menurunnya PAD Kota Surabaya. Penelitian kedua dilakukan oleh Albar Prastya Nugraha dan Hananto Widodo (2020) dengan judul "Penegakan Hukum Terhadap Pelanggaran Izin Reklame di Kota Surabaya". Penelitian tersebut menyoroti mengenai pelanggaran perizinan reklame di Surabaya. Penelitian ketiga dilakukan Risma Wulansari (2014) dengan judul "Penerapan Sanksi Administrasi Terhadap Penyimpangan Penyelenggaraan Reklame di Kota Malang Berdasarkan Perwali Malang No. 19 Th. 2013". Penelitian ini menyoroti sanksi administrasi yang dilakukan terhadap penyimpangan penyelenggaraan reklame dalam perizinan reklame.

\section{METODE}

Jenis penelitian ini adalah socio-legal. Penelitian dalam cara socio-legal dilakukan dengan mengumpulkan data lapangan, seperti menggunakan metode wawancara dan pengamatan. ${ }^{30}$ Penelitian socio-legal berkaitan pula dengan kejadian yang ada di masyarakat (empirik); sehingga peneliti menggunakan data hukum penunjang. Bahan hukum utama peneliti berupa hasil wawancara dengan stakeholder terkait (BPKPD). Kemudian, bahan hukum sekunder peneliti berupa Peraturan Walikota Surabaya Nomor 21 Tahun 2018 Tentang Tata Cara Penyelenggaraan Reklame, artikel jurnal dan buku teks yang membahas berkenaan dengan isu hukum yang dikaji. Sedangkan, bahan hukum tersier peneliti berupa kamus, ensiklopedia, majalah, dan sebagainya. Ketiga bahan hukum tersebut

30 Bambang Waluyo, Penelitian Hukum Dalam Praktek (Jakarta: Sinar Grafika, 2008). at 5. 
dikaji dan kemudian ditarik kesimpulan. Metode penelitian yang digunakan adalah kualitatif, oleh sebab data yang digunakan adalah bahan keterangan hasil wawancara yang diperoleh langsung dari BPKPD Kota Surabaya. Pendekatan penelitian ini menggunakan pola deskriptif. Sehingga, proses yang dilakuakan peneliti dapat menentukan arti atau definisi hukum yang menjadi pegangan untuk menyelesaikan permasalahan hukum yang menjadi objek kajian. ${ }^{31}$ Sedangkan untuk data penunjang, diperoleh dari berkas-berkas resmi, kepustakaan yang berhubungan dengan studi ini. Teknik akuisisi data pada penelitian ini dilakukan dengan mengidentifikasi dan menelusuri data atau dokumen seperti peraturan perundangundangan yang berkaitan dengan masalah penelitian, buku, dokumen resmi, literatur, dan karya ilmiah. ${ }^{32}$ Penelitian ini bertujuan untuk mengetahui problematika implementasi penegakan hukum terhadap keterlambatan pembayaran pajak reklame di Surabaya; sekaligus mengetahui keefektifan penegakan hukum terhadap keterlambatan pembayaran pajak reklame di Surabaya menurut Perwali TCPR.

\section{ASPEK REGULASI DAN KEWENANGAN PENEGAKAN HUKUM ATAS PAJAK REKLAME DI SURABAYA}

Pasal 1 angka 16 Perwali TCPR memberi pengertian bahwa reklame adalah sebuah objek, sarana, sikap, maupun wadah yang menurut bentuk dan desainnya untuk tujuan untuk mendapatkan keuntungan dari pembelian produk yang diiklankan, fungsinya membuat konsumen kenal, menginginkan, dan membeli suatu produk barang, jasa, atau orang, penempatan reklame harus di tempat yang terlihat;

31 Ibid. at 107.

32 Ammirudin \& H Z Asikin, Pengantar Metode Penelitian Hukum (Jakarta: Rajawali Pers, 2010). at 68. 
sehingga reklame dapat dibaca atau bahkan didengar oleh khalayak umum, kecuali dilakukan reklame untuk kepentingan pemerintah di pusat maupun daerah. Pada saat ini misalnya, contoh reklame yang dilakukan untuk kepentingan pemerintah adalah reklame yang berisikan informasi yang perlu disampaikan pemerintah kepada khalayak umum; contohnya himbauan mengenai penggunaan masker saat pandemi COVID-19 atau himbauan mengenai pelaporan pajak oleh pemerintah.

Penagihan Pajak Reklame dilakukan BPKPD) oleh karena, menurut Perwali TCPR, pemohon reklame mengajukan permohonan secara tertulis dengan mengisi formulir permohonan dan Surat Pemberitahuan Pajak Daerah (selanjutnya disebut dengan SPPD) yang disediakan BPKPD. Kemudian, menurut Pasal 1 angka 37 Perwali TCPR, bagi wajib pajak yang ingin memberikan laporan perhitungan dan pembayaran pajaknya; maka wajib pajak dapat menggunakan SPPD sesuai peraturan yang berlaku. Penegakan penertiban pembayaran Pajak Reklame juga dilakukan BPKPD; oleh karena, BPKPD memiliki tugas untuk mengolah dan mengatur pendapatan Kota Surabaya yang didapatkan dari pajak daerah. Ada beberapa jenis reklame yang disebutkan dalam Pasal 1 angka 17 sampai dengan angka 26 Perwali TCPR.

Pertama, reklame papan; reklame ini adalah iklan yang memuat produk yang sifatnya tetap karena tidak bisa dipindahkan, bahan pembuatnya bisa dari besi, kayu, 'seng', atau bahan lainnya dengan peletakkan di pinggir jalan atau di dinding (digantungkan); atau lahan lain orang lain dengan izin pemilik lahan juga dengan diberi penerangan atau tidak diberi penerangan. Kedua, Reklame Totem (sculpture); reklame ini bersifat tetap, oleh karena tidak dapat dipindahkan, berbentuk seperti patung atau benda yang dibentuk dari besi, katu, atau bahan lainnya yang dapat dibentuk, terletak 
dipinggir jalan atau digantungkan, atau juga diletakkan di lahan orang lain dengan izin pemilik lahan. Bentuknya seperti patung atau miniatur dari produk yang dipromosikan. Ketiga, reklame baliho; biasanya reklame baliho memiliki bentuk seperti papan atau selebaran kain atau kertas yang diletakkan pada suatu bangunan; biasanya ditempel di dinding atau tempat lain yang terlihat.

Keempat, reklame kain; reklame ini terbuat dari kain, biasanya mempromosikan suatu acara atau kegiatan sifatnya juga temporer atau sementara selama acara tersebut dilaksanakan. Kelima, reklame selebaran; reklame ini berbentuk selebaran kertas yang biasanya sering ditemui seperti halnya brosur-brosur motor, brosur diskon restoran baru yang dibagikan oleh orang di pinggir jalan kepada calon pembeli. Keenam, reklame melekat atau stiker; reklame ini dilekatkan di tempat-tempat yang dapat menarik perhatian dengan desain yang unik serta warna yang mencolok. Ketujuh, reklame film atau slide; iklan ini berwujud video yang ditampilkan, penyebutan lainnya videotron. Kedelapan, reklame udara; reklame ini bentuknya diterbangkan seperti balon udara atau bentuk lainnya. Kesembilan, reklame suara; reklame ini berupa rekaman suara yang diputar di pengeras suara atau saluran media elektronik lainnya. Kesepuluh, reklame peragaan; reklame ini berupa peragaan yang dilakukan oleh seseorang dan cenderung tanpa suara.

Lalu, bagaimana apabila seseorang -wajib pajak- berkehendak melakukan penyelenggaraan reklame sebagaimana yang disebutkan di atas? Langkah awal yang harus dilakukan penyelenggara reklame sebagai wajib pajak adalah melakukan perizinan reklame. Setelah itu, wajib pajak mendaftarkannya; wajib pajak akan mendapatkan Surat Ketetapan Pajak Daerah (SKPD) yang isinya ketetapan besarnya pajak, waktu jatuh tempo, dan data-data penyelenggara reklame 
yang lain. Berikut alur pendaftaran dan penegakan hukum pembayaran pajak reklame di Surabaya berdasarkan Perwali TCPR:

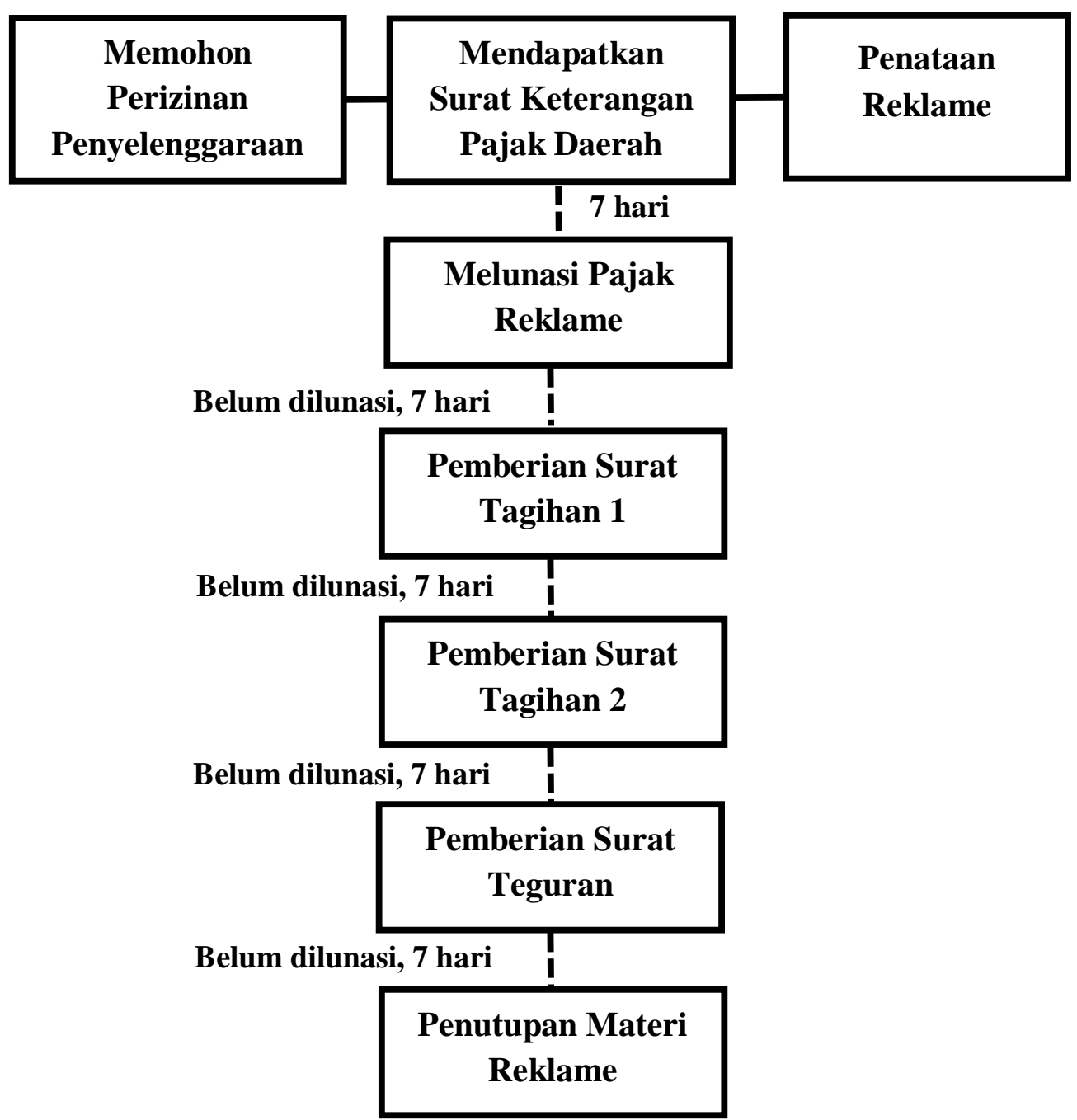

Bagan 1. Prosedur Penyelenggaraan Reklame di Badan Pengelola Keuangan dan Pajak Daerah Kota Surabaya

Sumber: Wawancara dengan Ibu Lyta selaku stakeholder pada 24 November 2020 dan Perwali TCPR 


\begin{abstract}
Mengajukan permohonan, mengisi formulis dengan membawa salinan KTP, salinan NPWP, surat kuasa bermaterai (bila diwakilkan), surat persetujuan pemilik lahan (bila di lahan milik orang lain), sketsa lokasi reklame, desain reklame, foto terbaru rencana lokasi reklame dengan ukuran $4 R$, SIPR sebelumnya (jika melakukan perpanjangan)
\end{abstract}

$\longrightarrow \begin{array}{lr}\text { Petugas } & \text { Badan } \\ \text { Pengelola } & \text { Keuangan } \\ \text { dan Pajak } & \text { Daerah } \\ \text { memeriksa kelengkapan } & \text { formulir ran } \\ \text { kelengkapan lainnya }\end{array}$

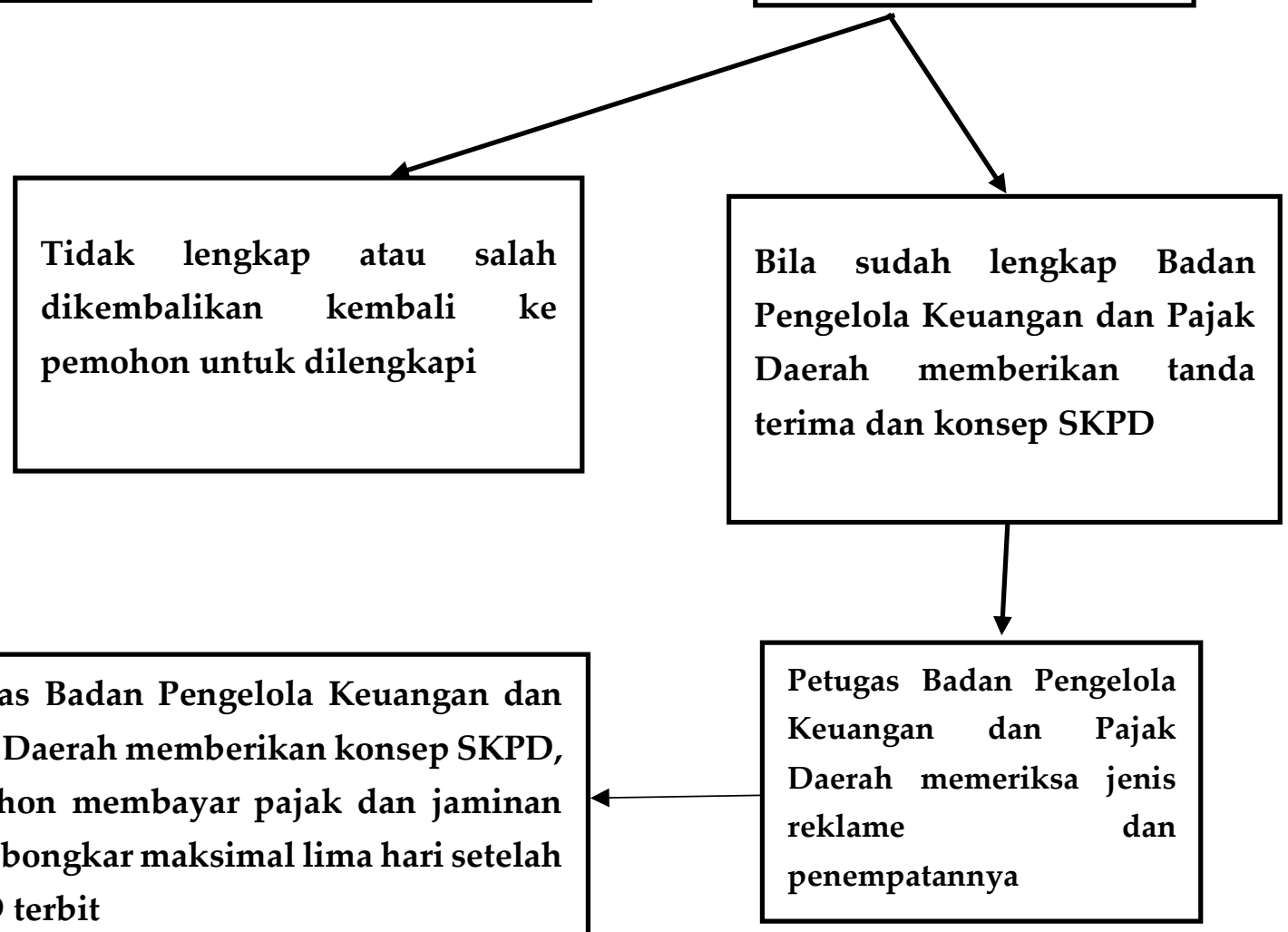
SKPD terbit

Petugas Badan Pengelola Keuangan dan Pajak Daerah memberikan konsep SKPD, pemohon membayar pajak dan jaminan biaya bongkar maksimal lima hari setelah

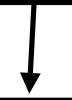

\begin{tabular}{l}
\hline Petugas Badan Pengelola \\
Keuangan dan Pajak Daerah \\
memberikan SKPD dan SSJB \\
sebagai tanda terima bahwa \\
pemohon telah membayar pajak
\end{tabular}

$\longrightarrow$\begin{tabular}{l|l|} 
Petugas Badan Pengelola \\
Keuangan dan Pajak Daerah \\
memberikan SIPR dan plat izin \\
sesuai SSPD kepada pemohon
\end{tabular}

Bagan 2. Proses Pendaftaran Reklame Permanen di Badan Pengelola Keuangan dan Pajak Daerah Kota Surabaya 
Berdasarkan keterangan stakeholder, implementasi penegakan hukum pelanggaran pajak reklame disikapi setara, baik itu reklame insidentil dan permanen. Perbedaan terjadi pada reklame terbatas; oleh karena, penyelenggarannya diajukan sesuai dengan permintaan pemohon. Misalnya, pemohon mengajukan penyelenggaraan reklame selama sepuluh hari; maka saat waktu penyelenggaraan telah habis, reklame tersebut akan dicabut oleh Satuan Polisi Pamong Praja (Satpol PP). ${ }^{33}$ Perlu diketahui, wajib pajak wajib membayarkan pajak reklame setelah mendapatkan SKPD. Apabila pajak reklame ini tidak dibayarkan mulai dari keluarnya SKPD sampai waktu jatuh tempo dan diberi masa tujuh hari; maka wajib akan dikirimkan Surat Tagihan Pertama (STP).

Bilamana setelah STP dikirimkan dan diberi waktu selama tujuh hari oleh BPKPD namun wajib pajak tidak segera membayarkan pajak reklamenya juga, maka BPKPD akan mengirimkan Surat Tagihan Kedua (STK) dengan waktu jatuh tempo tujuh hari setelah diterbitkannya STK. Apabila setelah waktu jatuh tempo wajib pajak juga masih belum membayarkan pajak reklamenya, maka BPKPD akan mengirimkan Surat Teguran. Surat Teguran ini memiliki waktu jatuh tempo selama tujuh hari. Setelah Surat Teguran ini diterbitkan dan masih belum dibayarkan pajak reklamenya oleh wajib pajak, maka BPKPD akan memberi spanduk untuK menutupi reklame dengan teks yang bertuliskan "MATERI INI BELUM MEMBAYAR PAJAK REKLAME".

Manakala selama tujuh hari belum dibayarkan pula oleh wajib pajak, maka BPKPD akan memerintahkan Satpol PP untuk membongkar reklame tersebut. Sayangnya, penegakan hukum dalam pembayaran

${ }^{33}$ Wawancara dengan Bu Ertina Mardhayanti P. selaku Kepala Sub Bidang Penagihan dan Pengurangan Pajak Reklame, Hiburan, dan Air Tanah pada hari Selasa tanggal 16 Maret 2021 
pajak reklame sendiri masih banyaknya pelanggaran yang terjadi, akibatnya banyak reklame yang ditutup bahkan dibongkar oleh Badan Pengelola Keuangan dan Pajak Daerah Kota Surabaya. Data yang didapatkan penulis dari BPKPD pada tahun 2016-2020 sebagai berikut:

\begin{tabular}{|l|l|l|}
\hline \multicolumn{1}{|c|}{ BULAN } & $\begin{array}{c}\text { Target Penerimaan Pajak } \\
\text { Reklame }\end{array}$ & $\begin{array}{c}\text { Realisasi Penerimaan } \\
\text { Pajak Reklame }\end{array}$ \\
\hline 2016 & $\operatorname{Rp} 129.020 .000 .000$ & $\operatorname{Rp~132.291.866.992~}$ \\
\hline 2017 & $\operatorname{Rp} 131.161 .200 .000$ & $\operatorname{Rp~131.297.144.500~}$ \\
\hline 2018 & $\operatorname{Rp} 133.730 .872 .000$ & $\operatorname{Rp} 139.057 .010 .250$ \\
\hline 2019 & $\operatorname{Rp} 135.665 .000 .000$ & $\operatorname{Rp} 140.830 .670 .000$ \\
\hline 2020 & $\operatorname{Rp} 110.593 .889 .000$ & $\operatorname{Rp} 99.663 .900 .000$ \\
\hline
\end{tabular}

Tabel 1. Data Target dan Realisasi Pajak Reklame Surabaya Tahun 2016-2020

Sumber: Wawancara dengan Ibu Ertina Mardhayanti P. selaku Kepala Sub Bidang Penagihan dan Pengurangan Pajak Reklame, Hiburan, dan Air Tanah pada hari Selasa tanggal 9 April 2021

Data target dan realisasi pajak reklame Surabaya di atas menunjukkan bahwa penerimaan pajak reklame di Surabaya mencapai target penerimaannya. Hanya saja, pada tahun 2020 penerimaan pajak reklame diketahui menurun; oleh karena adanya penyesuaian pandemi COVID-19 serta kondisi Kota Surabaya yang menerapkan kebijakan Pembatasan Sosial Berskala Besar (PSBB). Salah satu fenomena yang terjadi manakala terdapat pelanggaran yang dilakukan oleh restoran yang terletak di dalam mall di 
Surabaya. ${ }^{34}$ Restoran tersebut mendaftarkan dua reklame pada BPKPD. Namun, restoran tersebut tak kunjung membayarkan pajak reklama

Pada akhirnya, Surat Teguran yang ditujukan kepada pemilik restoran pada tanggal 15 Juni 2020 dilayangkan oleh BPKPD. Surat Teguran tersebut berisi teguran untuk pemilik restoran agar segera membayarkan pajak maksimal pada tanggal 23 Juni 2020. Dengan demikian, pemilik restoran tersebut menerima surat tagihan pertama pada tanggal 28 Mei 2020; kemudian menerima surat tagihan kedua pada 5 Juni 2020. Hanya saja, sampai dengan pada tenggat waktu yang ditentukan; pemilik restoran tidak segera membayarkan pajak reklamenya. Sehingga, BPKPD menutup reklamenya dengan tulisan "MATERI INI BELUM MEMBAYAR PAJAK REKLAME"; oleh karena, pemilik restoran baru membayarkan pajak reklamenya pada tanggal 30 Juni 2020 yang jelas melanggar jatuh tempo yang telah ditetapkan BPKPD. Restoran tersebut diklaim telah melanggar Pasal 30 ayat (2) Peraturan Daerah Kota Surabaya Nomor 4 Tahun 2011 Tentang Pajak Daerah.

Kasus tersebut menunjukkan bahwa BPKPD melakukan setiap tahapan sesuai dengan asas umum pemungutan pajak dan asas certainty; yaitu pajak yang harus dibayar oleh wajib pajak harus terang (certain) dan tidak mengenal kompromis (not arbitary). Oleh sebab, sudah jelas dalam SKPD, nomimal pajak harus dibayarkan oleh wajib pajak pada saat waktu jatuh tempo; serta tidak ada kompromi untuk keterlambatan pembayaran pajak. Selain itu, reklame yang dipasang oleh pemilik restoran juga merupakan

34 Fatimatuz Zahro, "Reklame Tak Bayar Pajak Diberi Spanduk seperti ini, Pemkot: Masak Gak Malu", Trib Surabaya (November 2017), online: $<$ https://surabaya.tribunnews.com/2017/11/26/reklame-tak-bayar-pajakdiberi-spanduk-seperti-ini-pemkot-masak-gak-malu>. 
billboard; yaitu reklame yang bersifat tetap (tidak dapat dipindahkan) sebagaimana sesuai dengan Pasal 1 angka 17 Perwali TCPR. Telah menjadi tugas BKPPD pula untuk melakukan pengawasan salah satunya dalam pemenuhan pembayaran pajak reklame oleh wajib pajak, sehingga wajar BPKPD mengeluarkan surat tagihan serta surat teguran kepada pemilik restoran selaku wajib pajak.

Adanya keterlambatan pembayaran pajak ini dapat dikenakan sanksi administrasi. Sanksi tersebut diwujudkan dengan membayar denda dalam bentuk uang oleh karena telah melanggar kebijakan atau peraturan. ${ }^{35}$ Indikator sanksi administrasi antara lain keterlambatan membayar pajak dan pengenaan sanksi administrasi. Hal ini menjadi salah satu penyebab adanya sanksi administratif. Saat pajak tidak dibayarkan, maka pihak yang memiliki kewenangan akan melakukan penagihan serta pengenaan sanksi administrasi; salah satu contohnya yang dilakukan oleh BPKPD yang melakukan penagihan kepada wajib pajak reklame dan mengenakan biaya bongkar bagi reklame yang pada akhirnya harus dibongkar. Adapula indikator pengenaan sanksi denda sesuai dengan Pasal 7 ayat 1 Undang-Undang Nomor 28 Tahun 2007 Tentang Perubahan Ketiga Atas Undang-Undang Nomor 6 Tahun 1983 Tentang Ketentuan Umum dan Tata Cara Perpajakan.

Tinggi rendahnya kesadaran membayar pajak salah satunya dipengaruhi oleh tingkat pelayanan pembayaran pajak pula. Semakin baik, mudah, dan sederhana proses pembayaran pajak; maka akan membuat wajib pajak merasa nyaman dan rajin untuk

35 Rizki Amalia, "Pengaruh Pengenaan Sanksi Administrasi dan Kesadaran Wajib Pajak Terhadap Tingkat Wajib Pajak Kendaraan Bermotor" (2016) 31:1 J Adm Bisnis JAB. at 37. 
melaporkan dan membayarkan pajaknya. ${ }^{36}$ Di sisi lain, sistem perpajakan sekarang memberi kemudahan untuk menghitung, memperhitungkan, membayar, dan melaporkan sendiri besarnya pajak yang harus dibayar. ${ }^{37}$ Pelayanan pajak reklame sendiri pada prinsipnya sangat mudah; oleh karena, pajak reklame merupakan pajak yang dihitungkan oleh fiskus, sehingga wajib pajak hanya perlu membayarkan pajaknya saja. Berbeda dengan pajak-pajak yang menggunakan sistem penghitungan dan pelaporan pajak oleh wajib pajak sendiri. Menurut peneliti, berkenaan dengan mekanisme pembayaran pajak reklame di Surabaya, sebenarnya sudah sangat mudah dan sederhana. Terlihat dari proses yang dianalisa peneliti berdasarkan Perwali TCPR dan hasil wawancara dengan staf BPKPD; wajib pajak hanya perlu datang ke bagian pembayaran, lalu setelah mendapat nomor antrian, wajib pajak akan dipanggil dan dapat mengurus pembayaran serta administrasi lain di loket-loket yang tersedia.

Tujuan ditetapkannya Perwali TCPR adalah memberikan kepastian hukum yang jelas berkenaan dengan tata cara pemasangan reklame. Kepastian hukum tersebut berpengaruh terhadap keadilan hukum sebagai tujuan hukum. Bila diperhatikan lagi, sebenarnya pembangunan reklame di daerah tidak berhubungan dengan adanya kepastian hukum secara langsung; adanya reklame lebih mengarah pada perluasan promosi produk. Namun, kepastian hukum yang dimaksud dalam Perwali TCPR adalah teknis dalam penyelenggaraan reklame agar semua sesuai aturan dan tidak

36 Indah A Sulviane, Harianto \& Dedi B Hakim, "Strategi Peningkatan Penerimaan Pendapatan Pajak Reklame di Kabupaten Bogor" (2014) 6:1 J Manaj Pembang Drh. at 16.

37 Johny Subarkah \& Maya W Dewi, "Pengaruh Pemahaman, Kesadaran, Kualitas, Pelayanan, dan Ketegasan Terhadap Kepatuhan Wajib Pajak Orang Pribadi di KPP Pratama Sukoharjo" (2017) 17:2 J Akunt Dan Pajak. at 69. 
menyimpang; mulai dari perizinan sampai pengawasan serta pemberian sanksi. Menurut Pasal 4 ayat (1) Peraturan Walikota Surabaya No. 70 Th. 2016 Tentang Kedudukan, Susunan Organisasi, Uraian Tugas dan Fungsi Serta Tata Kerja Badan Pengelola Keuangan dan Pajak Daerah Kota Surabaya (selanjutnya disebut dengan Perwali BPKPD), tugas BPKPD adalah melaksanakan kewenangan dan tugas pembantuan sehingga menjadi penyokong bantuan bagi walikota.

Sebaliknya menurut Pasal 4 ayat (2) Perwali BPKPD, fungsi BPKPD antara lain menerapkan teknis peraturan, melaksanakan tugas pembantuan, memantau, memberikan nilai, serta melaporakan pelaksanaan tugas pembantuan, pembinaan penyelenggaraan fungsi penunjang urusan pemerintahan daerah, dan melakukan perintah walikota sesuai lingkup dan tugas serta fungsinya. Menurut Peraturan Walikota Surabaya No. 46 Th. 2017 Tentang Petunjuk Teknis Penerapan Sistem Online Tehadap Pajak Daerah Kota Surabaya, kewenangan BPKPD antara lain mengatur sistem pembayaran pajak secara online, menangani laporan penyetoran pajak, dan menangani penerapan sanksi administratif.

Harus diketahui pula, asas equality yang diterapkan oleh BPKPD menunjukkan bahwa pengenaan jumlah pajak dengan jumlah upah yang diterima oleh wajib pajak harus seimbang. Selain itu, nilai pajak yang dibayarkan harus jelas jumlahnya; dan lebih baik pajak dikenakan pada saat terdekat penerimaan pendapatan wajib pajak. ${ }^{38}$ Oleh karena, teori pemungutan pajak menyebutkan bahwa pajak dianalogikan sebagai asuransi yang harus dibayarkan; karena dalam pengenaan pajak, ada perlindungan hak-hak wajib pajak oleh pemerintah. Selain itu, wajib pajak diharapkan membayar pajak

38 R Santoso Brotodiharjo, Pengantar Ilmu Hukum Pajak (Bandung: Refika Aditama, 2010) at 27-28. 
sesuai dengan kemampuannya masing-masing; semakin besar kepentingan dalam reklame serta semakin besar keinginan konsumen ingin memiliki produk yang dipromosikan, maka pajaknya akan semakin tinggi pula. Oleh sebab, dekorasi reklame yang semakin menarik perhatian, mengakibatkan wajib pajak harus membayar pajak yang besar juga. Pajak merupakan sebuah kewajiban penuh daro wajib pajak sebagai warga negara; pajak sendiri juga dikenakan oleh masyarakat dan untuk masyarakat pula sebagai bentuk perilaku gotong royong dalam membangun fasilitas umum yang menjadi ciri khas Bangsa Indonesia. ${ }^{39}$ Dengan demikian, berdasarkan berbagai analisa peneliti di atas, BPKPD memiliki wewenang untuk menarik pajak; dan masyarakat yang bersangkutan memiliki kewajiban untuk membayar pajak tanpa bisa ditawar kembali. Maka dari itu, sanksi bagi yang tidak segera melunasi pajak reklame adalah penutupan materi reklame; sampai dengan sanksi administratif sebagai wujud penegakan hukum oleh.

Penegakan hukum dapat dipandang dari beberapa sisi, yaitu sisi administratif dan sisi normatif. ${ }^{40}$ Harus dipahami, penegakan hukum oleh BPKPD termasuk dalam dimensi sistem administratif. BPKPD sebagai aparatur penegak hukum melakukan interaksi dan sinergi dengan subjek yang dikenai hukum; dan kemudian menimbulkan sebuah sistem penegakan hukum yang normatif dengan adanya sikap penutupan materi reklame bagi wajib pajak yang tidak segera membayarkan pajak reklamenya. Meskipun demikian, penegakan hukum juga harus mendatangkan kemanfaatan sosial selain untuk mendapatkan kepastian hukum. ${ }^{41}$ Oleh karena itu, penegakan

39 Ibid.

40 Muladi, Bunga Rampai Hukum Pidana (Bandung: Alumni, 1995) at 41.

41 Novi D R Wheny, Penegakan Hukum Bagi Penyalahgunaan Narkoba Saat Proses Penyidikan (Studi Kasus di Polres Bangil) Universitas Muhammadiyah Malang, 2017) [unpublished]. at 11. 
hukum merupakan upaya untuk menegakkan keadilan dengan menertibkan masyarakyat agar sesuai dengan lalu lintas hukum; agar terwujud kepastian, kemanfaatan, dan keadilan sebagai tujuan hukum.

Penegakan hukum adalah usaha mencapai ide dan konsep hukum. ${ }^{42}$ Pelaksanaan hukum oleh penegak hukum dan orang-orang yang memiliki kepentingan sesuai aturan yang berlaku merupakan arti lain dari penegakan hukum. ${ }^{43}$ Secara konsep, dasar serta sikap selaku rangkaian untuk menghasilkan, memelihara, serta mempertahankan pergaulan hidup yang damai menjadi pokok penegakan hukum pada proses menyelaraskan keterkaitan sosial. ${ }^{44}$ Di tinjau dari sudut subjektif, penegakan hukum melibatkan semua subjek hukum dalam setiap hubungan hukum. Sedangkan dalam arti sempit, penegakan hukum hanya diartikan sebagai upaya aparatur penegakan hukum tertentu untuk menjamin dan memastikan bahwa suatu aturan hukum berjalan sebagaimana seharusnya. Namun, dilihat dari sudut objektif norma hukum yang hendak ditegakkan mencakup pengertian hukum formal dan hukum materiel. ${ }^{45}$ Penegakan hukum harusnya mewujudkan keinginan atau tujuan dari sebuah aturan, biasanya bersifat implisit berasal dari pemikiran perancang aturan.

Menurut peneliti, penegakan hukum pajak tidak bermaksud untuk memaksa dan mengancam para pelaku yang terlambat atau bahkan tidak membayarkan pajaknya kepada pemerintah daerah, karena hal ini lebih bersifat represif. Sosialisasi, penyuluhan, serta pembelajaran pajak untuk warga merupakan perihal yang memiliki hubungan dan

42 Dellyana Shant, Konsep Penegakan Hukum (Yogyakarta: Liberty, 1998) at 32.

43 Harun M Husen, Kejahatan dan Penegakan Hukum di Indonesia (Jakarta: Rineka Cipta, 1990) at 58.

44 Soerjono Soekanto, Sosiologi Hukum dalam Masyarakat (Jakarta: Rajawali Pers, 1987) at 5.

45 Sudarto, Hukum dan Hukum Pidana (Bandung: Alumni, 1986) at 151. 
arti khusus terhadap penegakan hukum pajak; sebagaimana seringkali dilakukan oleh pemerintah daerah untuk mendorong pembayaran pajak yang tepat waktu. ${ }^{46}$

Hal senada diungkapkan oleh Soerjono Soekanto bahwa penegakan hukum adalah kegiatan yang bertujuan untuk menjaga saling pengaruh nilai-nilai yang dijabarkan dalam prinsip dan relasi yang kokoh sebagai rangkaian distribusi nilai akhir yang terstruktur untuk menciptakan perdamaian dan pemeliharaan. ${ }^{47}$ Jimly Asshiddiqie juga mengatakan bahwa lembaga penegak hukum yang mengambil langkah-langkah untuk menegakkan hukum wajib mematuhi aturan hukum sebagai pedoman hubungan hukum dalam kehidupan publik dan nasional. ${ }^{48}$ Oleh karena itu, penegakan hukum oleh BPKPD merupakan salah satu contoh upaya untuk menegakkan normanorma hukum; sehingga, dapat menjadi pedoman perilaku hubungan hukum dalam kehidupan bermasyarakat dalam bidang perpajakan daerah.

Penegakan hukum dapat dibagi menjadi tiga bagian. Pertama, total enforcement; artinya hukum pidana substantif digunakan untuk merumuskan hukum pidana, oleh karena aparat penegak hukum terikat dan dibatasi oleh hukum acara pidana yang saling terkait; dan mengakibatkan mereka tidak dapat diterapkan. Kedua, full enforcement; merupakan aplikasi umum yang diminimalkan dengan area no enforcement, sehingga dalam menghadapi suatu pelanggaran, lembaga penegak hukum diharapkan dapat memastikan kepatuhan

${ }^{46}$ Catur M Fajar, "Tax Law Enforcement Sebagai Upaya Optimalisasi Penerimaan Pajak Negara Ditinjau Melalui Tingkat Kepatuhan Wajib Pajak" (2014) 2:2 J Ecodemica. at 199.

47 Wheny, supra note 43 at 11.

48 SE Situngkir, "Penegakan Hukum Bidang Perpajakan dalam Rangka Meningkatkan Pendapatan Asli Daerah (Studi di Kota Pontianak)" (2017) 4:4 J Nestor Magister Huk. at 15. 
hukum secara penuh. Ketiga, actual enforcement; menunjukkan bahwa karena waktu, personel, penelitian, biaya, dan kendala lain actual enforcement dianggap tidak realistis. ${ }^{49}$

Menurut peneliti, penegakan yang dilakukan oleh BPKPD adalah actual enforcement, oleh karena penegakan yang BPKPD Kota Surabaya menunjukkan adanya waktu, personel, dan aturan yang terpengaruh adanya pandemi COVID-19; sehingga membatasi pergerakan untuk menagih pajak, maupun melakukan penegakan secara langsung kepada wajib pajak. Penegakan hukum yang dilakukan BPKPD biasanya dilakukan langsung dengan menemui para wajib pajak yang tercatat melanggar Perwali TCPR. Namun, karena pada tahun 2020 pemerintah pusat menghimbau untuk mengurangi mobilitas di luar ruang, BPKPD Kota Surabaya melakukan penagihan melalui surat yang dikirimkan kepada wajib pajak yang memiliki tanggungan pajak.

\section{PROBLEMATIKA DAN UPAYA PENEGAKAN HUKUM OLEH BADAN PENGELOLA KEUANGAN DAN PAJAK DAERAH KOTA SURABAYA}

Salah satu kendala yang dialami BPKPD adalah kurangnya kesadaran hukum penyelenggara reklame. Banyaknya pelanggaran oleh penyelenggara reklame yang tidak berkenan membayarkan pajak reklamenya membuat BPKPD mengirimkan pemberitahuan kepada penyelenggara reklame sekaligus wajib pajak ini melalui surat yang dikirimkan ke pemilik reklame. Meski telah dilakukan tindakan demikian, masih banyak pula wajib pajak yang tidak menghiraukan surat tagihan tersebut; sehingga BPKPD menerbitkan

49 Shant, supra note 44 at 39. 
surat teguran dan pada akhirnya materi reklamenya ditutup oleh BPKPD. ${ }^{50}$

BPKPD Kota Surabaya mengklaim kendala yang sering dihadapi adalah ketika wajib pajak sudah diberikan SKPD yang berisi waktu jatuh tempo pembayaran pajak dan jumlah pajak yang jelas; namun, penyelenggara reklame masih memiliki tagihan pajak reklame yang harus dibayar, meskipun reklame yang terpasang sudah terbongkar. Padahal, pada saat penyelenggaraan reklame tidak sesuai dengan Perwali TCPR, BPKPD membongkar reklame milik penyelenggara reklame. Lumrahnya, penyelenggara reklame -yang reklamenya telah dibongkar- berkelit dan tidak mau membayar tagihan pajaknya. Alasan yang selalu diberikan oleh penyelenggara reklame yang bermasalah tersebut adalah reklame yang ada dalam SKPD itu sudah dibongkar dan tidak ada lagi, sehingga pajak reklame yang belum dibayarkan tersebut dianggap tidak perlu dilunasi dan cenderung diabaikan. Padahal ini sudah merupakan salah satu kewajiban mutlak dalam pemungutan pajak.

Hambatan perpajakan berasal dari perlawanan pasif dan aktif. ${ }^{51}$ Perlawanan pasif berarti karena perkembangan intelektual pelaku yang tidak membayar pajak reklame, maka kedisiplinan pelaku reklame masih rendah. Kesalahaan (error), pelaku biasanya paham dan mengerti mengenai prosedur dan ketentuan peraturan perundang-undangan pajak reklame, tapi tidak mau membayar pajak (pasif) dan juga masih menghitung data dengan tidak benar.

50 Wawancara dengan Bu Ertina Mardhayanti P. selaku Kepala Sub Bidang Penagihan dan Pengurangan Pajak Reklame, Hiburan, dan Air Tanah pada hari Selasa tanggal 16 Maret 2021

51 Dian W Darmanto, "Penerapan Kebijakan Penataan dan Sistem Pemungutan Pajak Reklame Sebagai Sarana Penunjang Efektivitas" (2015) 4:12 J Lmu Ris Akunt. at 11. 
Sistem kontrol tidak dapat beroperasi secara normal, ini mungkin terjadi karena sumber daya manusia yang terbatas.

Perlawanan aktif, mencakup segala upaya dan tindakan yang diarahkan kepada otoritas pajak untuk menghindari perpajakan, termasuk Tax avoidance atau melakukan penghematan pajak yaitu upaya dengan tidak melanggar aturan dengan meningkatkan tanggungan pajak, Tax evasion atau penggelapan pajak yaitu upaya mengurangi tanggungan pajak dengan cara menyalahi ketentuan perundang-undangan, Tax loses atau kerugian pajak, yaitu selisih antara kekuatan pajak dengan penerimaan pajak aktual, disebut sebagai kerugian pajak dapat berupa kerugian yang disebabkan oleh peraturan perpajakan, kerugian oleh pejabat pajak, dan kerugian oleh wajib pajak. Namun yang terjadi pada penagihan reklame di Surabaya disebabkan oleh penyelenggara reklame yang tidak membayar pajak reklame.Kurangnya pengetahuan dari wajib pajak yang merasa apabila melanggar kewajiban pajaknya maka pajaknya akan langsung dibongkar. Bahkan, ketika wajib pajak diberi surat tagihan maupun surat teguran kebanyakan wajib pajak tidak merespon pemberitahuan tersebut, sehingga walaupun materi reklamenya ditutup wajib pajak tetap tidak merespon sehingga reklamenya dibongkar. ${ }^{52}$

Tetapi ketika memiliki pengetahuan mengenai sanksi perpajakan, pelaku akan mematuhi aturan-aturan perpajakan yang berlaku, adanya sanksi perpajakan ini secara parsial akan meningkatkan kepatuhan membayar pajak. Kepatuhan terjadi meningkat secara parsial karena dipengaruhi banyak faktor lain bisa ada pada penegak

52 Wawancara dengan Bu Lyta selaku staff penagihan pajak reklame Badan Pengelola Keuangan Dan Pajak Daerah Kota Surabaya pada Selasa 24 November 2020. 
hukum, para pekerja yang ada di bidang perpajakan, dan lain sebagainya. ${ }^{53}$

Adanya kendala penyesuaian pandemi COVID-19. Th. 2020 Badan Pengelola Keuangan Dan Pajak Daerah Kota Surabaya mengalami kendala penagihan ke para wajib pajak yang masih memiliki hutang pajak reklame dikarenakan adanya penetapan Pembatasan Sosial Berskala Besar (PSBB) oleh Pemerintah Kota Surabaya, sehingga waktu dan kegiatan keliling mendatangi wajib pajak berkurang. Sikap yang dilakukan dengan melakukan penagihan melalui surat tagihan yang dikirimkan ke wajib pajak. ${ }^{54}$ Berarti dalam penegakan pembayaran pajak reklame ini termasuk dalam actual enforcement. Keterbatasan waktu, personel, alat penelitian, sumber daya, dan lainlain mengarah kepada tingkat kebebasan tertentu, sehingga selebihnya disebut actual enforcement yang tidak dianggap sebagai harapan yang realistis. Badan Pengelola Keuangan Dan Pajak Daerah Kota Surabaya memiliki waktu dan regulasi yang terbatas, serta membutuhkan lebih sedikit aktifitas di luar ruangan dan menimbulkan keramaian di tempat-tempat umum.

Usaha yang dilakukan Badan Pengelola Keuangan Dan Pajak Daerah Kota Surabaya antara lain membongkar reklame yang tidak dilunasi pajaknya. Ketika penyelenggara reklame/wajib pajak tidak segera melunasi pajak reklamenya padahal Badan Pengelola Keuangan Dan Pajak Daerah Kota Surabaya sudah berusaha untuk menghubungi pemilik reklame melalui surat tagihan sampai dua kali pengiriman

53 Davidya Febri \& Tri Sulistyani, "Pengaruh Pengetahuan dan Pemahaman Peraturan Perpajakan, Penghindaran Pajak, dan Sanksi Perpajakan Terhadap Kepatuhan Wajib Pajak" (2018) 10:1 PERMANA. at 23.

54 Erik Erfinanto, "Realisasi Pendapatan Daerah Capai 35 Persen", Liputan6 (17 June 2020), online: <https:/m.liputan6.com/surabaya/read/4281064/realisasipendapatan-daerah-surabaya-capai-35-persen>. (Diakses pada tanggal 8 Mei 2021, pukul 17.15 WIB). 
dengan jarak waktu tujuh hari tiap surat tagihan yang pertama dan kedua, setelah surat tagihan kedua dikirimkan sampai waktu tujuh hari penyelenggara reklame/wajib pajak tidak juga segera membayarkan pajak reklamenya, BPKPD mengirimkan surat teguran untuk segera membayar pajak reklame, sampai tujuh hari pajak reklame tetap tidak dibayarkan maka materi reklame akan ditutup, bila setelah ditutup tidak juga dibayarkan, maka reklame akan dibongkar oleh BPKPD Kota Surabaya dengan bantuan Satpol PP. 55

Tetap melakukan penagihan melalui surat tagihan. Pandemi COVID19 yang menjadi hambatan BPKPD Kota Surabaya untuk melakukan penagihan secara langsung ke wajib pajak diganti dengan terus melakukan penagihan melalui surat yang dikirimkan ke wajib pajak. ${ }^{56}$ Padahal ketika dalam kondisi biasa BPKPD akan berkeliling mencari reklame yang belum membayar pajak maupun tidak berizin. Biasanya dengan berkeliling ini BPKPD bisa menemui pemilik reklame atau pemilik usaha untuk mengetahui hambatan apa yang dialami oleh pemilik reklame atau pemilik usaha sampai telat membayarkan pajak reklamenya karena kondisi keuangan perusahaan dapat mempengaruhi tingkat kepatuhan membayar pajak.

Kewajiban sosialisasi oleh pemerintah mengenai pentingnya pajak harus dilakukan agar wajib pajak memahami esensi pajak sebagai kontribusi pembangunan bangsa dan negara. Sosialisasi oleh pemerintah -dalam hal ini dilakukan oleh BPKPD- dapat dilakukan dengan dua cara. Pertama, dengan sosialisasi langsung; berarti

\footnotetext{
55 Wawancara dengan Bu Ertina Mardhayanti P. selaku Kepala Sub Bidang Penagihan dan Pengurangan Pajak Reklame, Hiburan, dan Air Tanah pada hari Selasa tanggal 24 November 2020

56 Erfinanto, supra note 56.
} 
BPKPD memberikan penyuluhan untuk bertemu langsung dan berinteraksi langsung dengan peserta yang diberikan penyuluhan. Kedua, sosialisasi atau penyuluhan tidak lansung; cara ini dilakukan oleh orang yang memberikan penyuluhan dengan tidak berinteraksi dan bertemu langsung dengan perserta penyuluhan, misalnya dengan menggunakan video conference. ${ }^{57}$

\section{KESIMPULAN}

Problematika penegakan hukum atas pajak reklame di Kota Surabaya ditunjukkan adanya kecurangan yang dilakukan oleh wajib pajak secara sengaja atau tidak sengaja. Kecurangan yang biasanya terjadi adalah manakala pemilik materi reklame sudah membayarkan biaya reklame kepada biro reklame; namun dari pihak biro reklame, tidak segera membayarkan pajak reklamenya sehingga materi reklame ditutup. Akibatnya, pemilik materi reklame yang pada akhirnya menerima sanksi. Bukan hanya itu, problematika yang ditemui oleh BPKPD adalah berkenaan dengan rendahnya tingkat kepedulian masyarakat dalam pembayaran reklame yang telah terdaftar di BPKPD Kota Surabaya. Kendala tersebut sering ditemui karena penyelenggara reklame atau wajib pajak merasa tidak memiliki kewajiban untuk melunasi pajak reklame, bahkan terhadap reklame yang telah dibongkar karena telah melanggar aturan. Perilaku tersebut dilakukan secara sengaja atau tidak sengaja oleh pelaku pelanggar aturan; konsekuensinya, BPKPD melakukan penangguhan kepada pelaku-pelaku pelanggar pajak reklame untuk mendaftarkan reklame baru. Kemudian, pelaku tersebut harus melunasi pajak dari

57 Marisa Heryanto \& Agus A Toly, “Pengaruh Kesadaran Wajib Pajak, Kegiatan Sosialisasi Perpajakan, dan Pemeriksaan Pajak Terhadap Penerimaan Pajak Penghasilan di KPP Pratama Surabaya Sawahan" (2013) 1:1 Tax Account Rev. At 127 
reklame lama yang telah dibongkar oleh BPKPD. Selain itu, kurangnya pemahaman wajib pajak tentang pengetahuan perpajakan, adanya pandemi COVID-19 juga menjadi kendala bagi BPKPD Kota Surabaya untuk melakukan penagihan dan interaksi secara langsung kepada wajib pajak. Terdapat perlawanan aktif dan pasif pula dari pelaku secara sengaja agar tidak membayar pajak yang harusnya menjadi tanggungannya. Padahal, penggelapan pajak yang melanggar aturan perpajakan ataupun penghematan pajak yang tidak melanggar aturan perpajakan tetap saja membuat kerugian bagi negara. Berbagai problematika tersebut mendorong BPKPD untuk melakukan penegakkan hukum yang berlaku; disamping meningkatkan kesadaran penyelenggara reklame atau wajib pajak untuk menaati aturan dengan cara membongkar reklame yang memang tidak dibayarkan pajak reklamenya, melakukan penagihan tidak langsung untuk menaati aturan yang dipengaruhi pandemi COVID-19 dengan cara mengirimkan surat tagihan kepada wajib pajak, dan senantiasa melakukan sosialisasi terhadap para wajib pajak yang kurang memiliki pemahaman terhadap pengetahuan perpajakan.

\section{DAFTAR PUSTAKA}

Ammirudin \& H Z Asikin, Pengantar Metode Penelitian Hukum (Jakarta: Rajawali Pers, 2010).

Brotodiharjo, R Santoso, Pengantar Ilmu Hukum Pajak (Bandung: Refika Aditama, 2010).

Husen, Harun M, Kejahatan dan Penegakan Hukum di Indonesia (Jakarta: Rineka Cipta, 1990).

Muladi, Bunga Rampai Hukum Pidana (Bandung: Alumni, 1995). 
Shant, Dellyana, Konsep Penegakan Hukum (Yogyakarta: Liberty, 1998).

Soekanto, Soerjono, Sosiologi Hukum dalam Masyarakat (Jakarta: Rajawali Pers, 1987).

Sudarto, Hukum dan Hukum Pidana (Bandung: Alumni, 1986).

Waluyo, Bambang, Penelitian Hukum Dalam Praktek (Jakarta: Sinar Grafika, 2008).

Wheny, Novi D R, Penegakan Hukum Bagi Penyalahgunaan Narkoba Saat Proses Penyidikan (Studi Kasus di Polres Bangil) Universitas Muhammadiyah Malang, 2017) [unpublished].

Ali Al-Ttaffi, Lutfi H, Said A Bin-Nashwan \& Muneer R Amrah, "The Influence Of Tax Compliance Behaviour: A Case of Yemeni Individual Taxpayers" (2020) 10:2 J Bus Manag Account.

Amalia, Rizki, "Pengaruh Pengenaan Sanksi Administrasi dan Kesadaran Wajib Pajak Terhadap Tingkat Wajib Pajak Kendaraan Bermotor" (2016) 31:1 J Adm Bisnis JAB.

Darmanto, Dian W, "Penerapan Kebijakan Penataan dan Sistem Pemungutan Pajak Reklame Sebagai Sarana Penunjang Efektivitas" (2015) 4:12 J Lmu Ris Akunt.

Delfia \& Aftoni Sutanto, "Pengaruh Biaya Reklame dan Periklanan Pada PT. PAPUA PASIFIK PERMAI JAYAPURA (Studi Kasus Periode 2014-2018)" (2020) 8:1 E-J Apresiasi Ekon.

Djaha, Permenas \& Ni Luh Putu Sri Purnama Pradnyani, "Faktor Pelayanan Publik, Informasi Perpajakan, dan Kepatuhan Wajib Pajak dalam Meningkatkan Kesadaran Masyarakat Membayar Pajak" (2019) 2:2 JEMAP J Ekon Manaj Akunt Dan Perpajak.

Erfinanto, Erik, "Realisasi Pendapatan Daerah Capai 35 Persen", Liputan6 
$<$ https:/m.liputan6.com/surabaya/read/4281064/realisasipendapatan-daerah-surabaya-capai-35-persen>.

Fajar, Catur M, “Tax Law Enforcement Sebagai Upaya Optimalisasi Penerimaan Pajak Negara Ditinjau Melalui Tingkat Kepatuhan Wajib Pajak" (2014) 2:2 J Ecodemica.

Febri, Davidya \& Tri Sulistyani, "Pengaruh Pengetahuan dan Pemahaman Peraturan Perpajakan, Penghindaran Pajak, dan Sanksi Perpajakan Terhadap Kepatuhan Wajib Pajak" (2018) 10:1 PERMANA.

Fuad, Khoirul \& Lutfi Khusfiyah, "Revealing Awareness and Compliance of Tax (Case Study in Tax Ofiice (KPP) Pratama Jepara" (2019) 4:2 J Appl Account Tax.

Fuadah, Luk Luk \& Umi Kalsum, "The Impact of Corpaorate Social Responsibility on Firm Value: The Role of Tax Aggresiveeness in Indonesia" (2021) 8:3 Tax Account Rev.

Heryanto, Marisa \& Agus A Toly, "Pengaruh Kesadaran Wajib Pajak, Kegiatan Sosialisasi Perpajakan, dan Pemeriksaan Pajak Terhadap Penerimaan Pajak Penghasilan di KPP Pratama Surabaya Sawahan" (2013) 1:1 Tax Account Rev.

June, Cindy G T, Unti Ludigdo \& Lilik Purwanti, “Menggali Makna Kepatuhan Wajib Pajak Usaha Mikro" (2021) 5:1 J Akunt Dan Pajak.

Kristanto, Ari B, "Faktor Finansial dan Non Finansial Yang Mempengaruhi Agresivitas Pajak Di Indonesia" (2016) 16:1 Media Ris Akunt Audit Inf.

Kumala, Ratih, “Factors That Influence MSME Taxpayer's Willingness to Pay Tax After the Implementation of the Government Rules Number 23 of 2018" (2019) 1:1 Ilomata Int J Tax Account. 
Mason, Ruth, "The Transformation of International Tax" (2020) 114:3 Am J Int Law.

Naharto, Michelle J \& Elisa Tjondro, “Analisis Tujuan Pemungutan Serta Pengertian Penghasilan Menurut Perpajakan dan Persepuluhan Bagi Wajib Pajak Orang Pribadi" (2014) 4:1 Tax Account Rev.

Parinduri, Rizka E et al, "Effect of Tax Amnesty and Government Expenditures on Economic Growth in Indonesia" (2020) 7:11 Int J Res Rev.

Permana, Hendra \& Nofryanti, "Pengaruh Faktor Pendidikan, Pengalaman Kerja, dan Pelatihan terhadap Pengetahuan Aparatur Pajak tentang Tax Avoidance (Studi Kasus Pada Kantor Pelayanan Pajak Pratama Kebayoran Baru Tiga)" (2016) 4:1 J Ilm Akunt Univ Pamulang.

Prakoso, Dimas B \& Wahyu Setiyorini, "Pengaruh Fraud Diamond Terhadao Indikasi Kecurangan Laporan Keuangan (Studi Pada Perusahaan Perkebunan yang Terdaftar di Bursa Efek Indonesia Tahun 2015-2019)" (2021) 7:2 J Akunt Dan Perpajak.

Prawati, Levana D \& Jesica P Uli Hutagalung, “The Effect of Capital Intensity, Executive Characteristics, and Sales Growth on Tax Avoidance" (2020) 7:1 J Appl Finance Account.

Pujiati, Nur I, Syamsu Alam \& Amiruddin, "Penggelapan Pajak Tinjauan Moral Perpajakan (Studi Kasus Kantor Pelayanan Pajak Pratama Makassar Selatan)" (2021) 4:1 AMNESTY J Ris Perpajak.

Putra, Wirmie E, Indra L Kusuma \& Maya W Dewi, “Analisis FaktorFaktor yang Mempengaruhi Kepatuhan Wajib Pajak (Studi Kasus pada Wajib Pajak Orang Pribadi dan Badan di Wilayah Kota Jambi" (2019) 20:1 J Akunt Dan Pajak. 
Putri, Vanya K M, “Jenis- Jenis Reklame”, Kompas.com (January 2021), online:

$<$ https://www.kompas.com/skola/read/202a/01/27/145328869/je nis-jenis-reklame>.

Saragih, Arfah H, "Pengaruh Penerimaan Pajak Terhadap Pertumbuhan Ekonomi di Indonesia" (2018) 3:1 Sist Inf Keuang Audit Dan Perpajak.

Saragih, Juli P, "Bauran Kebijakan Moneter- Fiskal Terhadap Pencapaian Target Inflasi dan Pertumbuhan Ekonomi" (2015) 20:2 Kajian.

Situngkir, SE, "Penegakan Hukum Bidang Perpajakan dalam Rangka Meningkatkan Pendapatan Asli Daerah (Studi di Kota Pontianak)" (2017) 4:4 J Nestor Magister Huk.

Subarkah, Johny \& Maya W Dewi, "Pengaruh Pemahaman, Kesadaran, Kualitas, Pelayanan, dan Ketegasan Terhadap Kepatuhan Wajib Pajak Orang Pribadi di KPP Pratama Sukoharjo" (2017) 17:2 J Akunt Dan Pajak.

Subroto, Gatot, "Knowledge Management in Tax Administration: A Case Study in Indonesia" (2020) 1:2 Scientax.

Sudirman, Sitti R, Darwis Lannai \& Hajering, "Pengaruh Norma Subjektif, Kewajiban Moral, dan Pemahaman Peraturan Pajak Terhadap Kepatuhan Wajib Pajak Pada KPP Pratama Makassar Utara" (2020) 3:2 AMNESTY J Ris Perpajak.

Sulviane, Indah A, Harianto \& Dedi B Hakim, "Strategi Peningkatan Penerimaan Pendapatan Pajak Reklame di Kabupaten Bogor" (2014) 6:1 J Manaj Pembang Drh.

Suryani, Indri \& Afriapollo Syafarudin, "Effect of Sales Promotion on Purchasing Decisions" (2021) 2:2 Ilomata Int J Tax Account. 
Susanto, Liana, Yanti \& Viriany, "Faktor-Faktor Yang Mempengaruhi Agresivitas Pajak" (2018) 23:1 J Ekon.

Tan, David \& Lu Sudirman, "Final Income Tax: A Classic Contemporary Concept To Increase Voluntary Tax Compliance Among Legal Profession in Indonesia" (2020) 5:1 J Indones Leg Stud.

Ur Rashid, Harun, “Taxpayer's Attitude Towards Tax Evasion in a Developing Country: Do the Demographic Characterics Matter?" (2020) 9:2 Int J Appl Behav Econ.

Wardani, Aditya K, Eva Anggra \& Amirah, "Pengaruh Karakteristik Perusahaan, Good Corporate Governance (GCG), dan Corporate Social Responsibility (CSR) Terhadap Penghindaran Pajak (Tax Avoidance)" (2016) 7:2 PERMANA.

Zahro, Fatimatuz, "Reklame Tak Bayar Pajak Diberi Spanduk seperti ini, Pemkot: Masak Gak Malu", Trib Surabaya (November 2017), online: <https://surabaya.tribunnews.com/2017/11/26/reklametak-bayar-pajak-diberi-spanduk-seperti-ini-pemkot-masakgak-malu>.

Wawancara dengan Bu Ertina Mardhayanti P. selaku Kepala Sub Bidang Penagihan dan Pengurangan Pajak Reklame, Hiburan, dan Air Tanah pada hari Selasa tanggal 16 Maret 2021

Wawancara dengan Bu Ertina Mardhayanti P. selaku Kepala Sub Bidang Penagihan dan Pengurangan Pajak Reklame, Hiburan, dan Air Tanah pada hari Selasa tanggal 24 November 2020

Wawancara dengan Bu Lyta selaku staff penagihan pajak reklame Badan Pengelola Keuangan dan Pajak Daerah Kota Surabaya pada Selasa 24 November 2020

Wawancara dengan Bu Lyta selaku staff penagihan pajak reklame pada 24 November 2020 